\title{
Contribution of draft cattle to rural livelihoods in a district of southeastern Uganda endemic for bovine parasitic diseases: an economic evaluation
}

Walter O. Okello ${ }^{1 *}$, Dennis Muhanguzi ${ }^{2}$, Ewan T. MacLeod ${ }^{1}$, Susan C. Welburn ${ }^{1}$, Charles Waiswa² and Alexandra P. Shaw ${ }^{3}$

\begin{abstract}
Background: A study was conducted in Tororo District in eastern Uganda to assess the socio-economic contribution of draft cattle to rural livelihoods. The aim of the study was to empirically quantify the economic value of draft cattle thus contributing to understanding the impact of endemic parasitic diseases of cattle on livestock productivity and subsequently household income, labor and food security.

Method: A total of 205 draft cattle keeping households $(n=205)$ were randomly selected and structured household questionnaires were administered, focusing on work oxen use, productivity, inputs and outputs. The data obtained was analyzed using standard statistical methods and used to calculate the gross margin from the draft cattle enterprise. Secondary data were obtained from focus group discussions and key informant interviews and these were analyzed using Bayesian methods.

Results: The study showed that, apart from being labor saving, the use of animal traction is highly profitable with the gross margin per year from the use of draft cattle amounting to 245 United States dollars per work oxen owning household. The cash obtained from hiring out draft animals was equivalent to nearly a quarter of the average local household's monetary receipts. It also revealed that endemic bovine parasitic diseases such as trypanosomiasis and tick-borne diseases reduced draft cattle output by $20.9 \%$ and potential household income from the use of draft oxen by $32.2 \%$.

Conclusion: The presence of endemic cattle diseases in rural Uganda is adversely affecting the productivity of draft cattle, which in turn affects household income, labor and ultimately food security. This study highlights the contribution of draft cattle to rural livelihoods, thus increasing the expected impact of cost-effective control strategies of endemic production limiting livestock diseases in Uganda.
\end{abstract}

Keywords: Draft cattle, Animal traction, Trypanosomiasis, Gross margin analysis, Household income, Uganda

\footnotetext{
* Correspondence: W.O.Okello@sms.ed.ac.uk

'Division of Infection and Pathway Medicine, School of Biomedical Sciences, College of Medicine and Veterinary Medicine, University of Edinburgh, Edinburgh, United Kingdom

Full list of author information is available at the end of the article
} 


\section{Background}

Animal traction refers to the use of domestic and partly domesticated animals for the purposes of tillage and transport [1]. The terms animal traction and draft animal power are used interchangeably. Worldwide, animal traction is an important reason for keeping livestock, particularly in poor rural societies, given that it is a costeffective 'labor-saving' technology for small scale and poor subsistence farmers compared to other forms of mechanization and the use of human power [2, 3]. Also, it is envisaged that these trends will continue in the near future as it is expected that agricultural intensification will rise due to increased population pressure and access to markets [4].

Studies have been carried out on animal traction in different parts of Africa, describing both draft output and other benefits. In western Africa, earlier studies comparing draft ox-owning households with non oxowning ones in Mali revealed that households with work oxen had better crop yields, lower labor requirements and higher incomes depending on the availability of fallow land [5]. More recent studies from Botswana, South Africa and Zimbabwe showed that draft cattle provided the highest proportion of livestock-derived income (up to $75 \%$ ) compared to milk, market sales and manure [6]. In eastern Africa, farmers using animal traction were found to have a higher yield and operated at a higher economic efficiency compared to those using hand held hoes [7]. In Ethiopia, better health and higher numbers of work oxen were clearly associated with an increase in cultivated area per household [8].

Despite its obvious benefits, active promotion of animal traction, and current research into the external social and economic drivers of its role in the fluid dynamics of farm operations, is limited [9]. These limited studies, coupled with the long time intervals required to study its impact, are thought to be contributing factors to the under estimation of the livestock sector's contribution to the gross domestic product hence cyclical under-funding of the sector in developing countries $[10,11]$. This situation is made worse by the perception that animal traction is considered "archaic" [7] and is therefore neglected in most agricultural policies [12].

Draft cattle are typically found in the mixed farming systems [13] particularly within the arid and semi-arid tropics and sub-tropics where crop-livestock interactions are common [14]. Also, in these regions and particularly sub-Saharan Africa, farmers face an immense challenge in keeping cattle productive, as a range of endemic parasitic and vector-borne diseases affect their livestock [15]. Thus, it is critical to assess the interaction between such diseases and work output from draft cattle [16, 17].

The main objective of the study was to determine the economic value of draft cattle enterprise using gross margin analysis, thus developing a standard evaluation method for assessment of animal traction in this area. Other objectives were to quantify the cost of endemic production-limiting diseases in cattle, contributing towards the wider research program on the cost-effectiveness of innovative farmer-led technologies to control these diseases [18].

At the farm level, gross margin analysis is normally used to assess the contribution of a particular crop, tree or livestock enterprise to farm income. To date, gross margin analysis has rarely been used for evaluating animal traction, although other methods such as multi-year partial budgeting [19], regression modeling [1, 20], production function modeling [7] and farm modeling [21] have been used in the past. Draft animal power is well captured by gross margin analysis given its dual role as a farm input in the form of traction, whilst simultaneously generating income through the sale or hiring of animals [22]. It also has the advantage of including changes in the herd value, accounting for the effects of changes in herd composition through births and deaths [23].

The study was done in 2012 in Tororo district. The district comprises an area of $1175 \mathrm{~km}^{2}$, bordering Kenya in southeastern Uganda. The major economic activity in the district is subsistence mixed farming, with over $80 \%$ of the population deriving their livelihood from agriculture [24]. The most common endemic vector-borne and parasitic bovine infectious diseases in Tororo district are: East Coast fever or theileriosis caused by Theileria parva [25]; babesiosis caused by Babesia bigemina; anaplasmosis caused by Anaplasma marginale; heartwater or cowdriosis caused by Ehrlichia ruminantium; gastroenteritis due to Haemonchus spp. infection; fascioliasis caused by Fasciola gigantica [26]; trypanosomiasis caused by Trypanosoma vivax, Trypanosoma brucei and Trypanosoma congolense [27]. In addition to animal African trypanosomiasis, human African trypanosomiasis (sleeping sickness) caused by Trypanosoma brucei rhodesiense is endemic in this district; impacting severely on human health and livelihoods in the region [28, 29]. It has also been reported that cattle restocking programmes from the district among others pose a risk of spreading human African trypanosomiasis to other regions in Uganda [30]. The most common method of controlling vector borne diseases in the study area is intermittent spraying with pyrethroids and amidines [31].

\section{Methods}

The list of all villages, which were considered as clusters, was obtained from the Ministry of Agriculture, Animal husbandry and Fisheries after which two stage cluster sampling [32] was carried out using CSurvey (University of California, Los Angeles, version 2.0) [33] to estimate the sample size. To avoid bias, this involved presenting the list of villages to an independent epidemiologist who 
assigned each village a number and then randomly chose a subset from the list. A total of 20 villages were thus selected at the first stage and then 10 households were chosen for the second stage with one person per household being eligible as a draft cattle owner. Based on information from the broader research project in Tororo district $[25,27]$, it was estimated that draft cattle owners were $20 \%$ of the cattle owning population in Tororo district. The desired level of confidence was $95 \%$ with one half of the confidence interval size being 0.09 . The variance estimate was estimated using design effect, which was set as low (i.e. 2.0). In total 205 draft cattle keeping households were interviewed $(n=205)$.

The household and livestock productivity structured questionnaires were administered to all participating households gathering information on household characteristics, livestock diseases, wealth indicators and a twelve month recall of herd dynamics. To select the participating households without bias, the spin dial for direction in CSurvey software was used to pin point the random start household [33]. Only households with draft cattle were interviewed. Focus group discussion and key informant interviews were concurrently utilized to complement the quantitative data [34]. A total of 18 focus group discussions and 28 key informant interviews were carried out on these themes. Apart from Akadot and Rukuli villages, which were not interviewed due to financial constraints, focus group discussions were conducted by selecting and having a discussion with a mixed group of cattle keepers, non cattle keepers, employed herdsmen, animal health technicians, women and business operators within each village. An average of 10.4 persons, with a standard deviation (SD) of 3.9, participated in the focus group discussions which were conducted in the evenings. The key informant interviews were conducted with the elected village chiefs (comprising the Local Council Level One), local veterinary staff and the heads of various women groups. All secondary data obtained from focus group discussions and key informant interviews were selected for stochastic modeling [35]. Uncertainty was modeled with a uniform distribution using upper and lower limits of the data obtained; and the use of Monte-Carlo simulation with 10000 iterations [36]. This enabled uncertainty to be incorporated in the final point estimate by adding a $95 \%$ credibility interval [35]. Statistical information obtained from the structured questionnaires was expressed as averages (mean) and their standard deviation was cited. The currency used in the data collection was Ugandan shillings, which are converted to United States Dollars (USD) at the exchange applicable at the time of the study (1 USD $=2325$ Ugandan shillings) [37].In order to use gross margin analysis to determine the overall contribution of draft cattle to household income, thus allowing for extrapolation to the district level, the draft cattle enterprise was analyzed using the following framework:

\section{GROSS MARGIN $=[$ LIVESTOCK OUTPUT $]$ -[VARIABLE COSTS]}

Where:

i) Livestock output $=(\mathrm{draft}$ animals and products sold/consumed/transferred/gifted 'out') - (draft cattle brought 'in' as purchases/transfers/gifts received) + (increase in herd value over 12 months);

ii) Variable costs $=$ cost of items used exclusively for draft cattle production and for which the quantity used varies in the short-term and in relation to the quantity of output.

According to the focus group discussions, the local price of labor paid during times of peak agricultural activity was USD 1.6 per day on average, with a credibility interval (CI) of 1.2-2; accordingly the value of family labor associated with draft cattle plowing was conservatively estimated to be $30 \%$ of this or USD 0.48 [38]. Conventionally, in farm budgets casual labor is considered a variable cost whereas family labor is considered at the fixed cost level. However, the use of animal traction is crucially bound up with changing labor requirements. It involves both labor cost specifically for managing draft animals and an overall labor saving due to their use. Accordingly, these varying labor components were, respectively, included in the variable costs and in livestock output, where the value of own-farm use of animal traction was based on the equivalent hand plowing labor saved. For the economic analysis, the household data was pooled, and then averages (mean) per household and per draft male calculated. The software $\mathrm{R}$ ( $\mathrm{R}$ development core team, version 3.2.1) was used for the statistical analyses [39].

\section{Ethical approval}

This study was among a set of other related studies reviewed by the Makerere University College of Veterinary Medicine Animal Resources and Biosecurity ethical review board for compliance to Animal use and Care Standards. It was then forwarded to the Uganda National Council for Science and Technology and approved under approval number HS1336.

\section{Results}

The average number of household members was 7.2 (SD 3.6), of whom 2.6 were adults over 18 years old and 4.6 children, with $97 \%$ of households being male-headed. The main occupation was agriculture: $93.4 \%$ of draft cattle keepers relied solely on crop and livestock farming, with only $6.8 \%$ deriving additional non-farm income 
(such as running local businesses or receiving cash from relatives who reside outside the district) . The average area cultivated per household was 3.6 acres (SD 1.7). Eighty three per cent of the farmers interviewed owned their own ox-plow, while none owned or used a tractor for plowing.

The total number of cattle owned by those participating in the study was 1003, with each household owning an average of 4.9 cattle; 0.3 sheep, 2.3 goats, 1.5 pigs, 11.6 chickens and 1.4 other livestock. Out of the 1003 cattle, there were 280 (27.9\%) work oxen (a term which refers to both bulls and castrated bulls in the study area, 270 (26.9 \%) adult females, 172 (17.1 \%) heifers, 158 (15.8\%) young males, 69 male calves $(6.9 \%)$ and 54 female calves $(5.4 \%)$ as shown in Table 1 . Among the calves in the herd there are thus 1.2 males to every female, reflecting the importance of draft power, with farmers indicating during focus group discussions that they give preferential care to male calves for this reason. Virtually all adult male cattle (bulls and oxen) were used for draft and young males were trained for the same purpose. No female cows were used for plowing.

The total number of draft cattle was 438, representing $43.7 \%$ of the sample households' cattle herd, with an average of 2.1 (SD 0.6) draft cattle owned per household as given in Table 2. This mean is very representative, since of the 205 households interviewed, 151 households had 2 draft cattle. Of the remainder, 20 households had only 1 draft bovine, 22 households had 3 draft cattle, 11 households had 4 draft cattle and 1 household had 6 draft cattle (Table 2). Since nearly $75 \%$ of all households have the same herd size ( 2 oxen) it was felt that analyzing the pooled data from the whole sample would provide representative results for the economic analysis.

At the start of the year leading up to this study, the total number of cattle comprised 1044 of which 349 were adult males and 136 young males. During that year 117 cattle died: 27 adult males, 8 young males, 24 cows, 21 heifers and 37 calves. Thus the herd mortality rate was $11.2 \%$ with draft cattle representing $29.9 \%$ of the total deaths. The reasons for cattle deaths were diseases, mentioned by $96.4 \%$ of the respondents, road accidents, mentioned by $2.2 \%$ of the respondents and $1.4 \%$ unknown. Data obtained from the structured questionnaire

Table 1 Herd structure of cattle among draft cattle keepers in Tororo district

\begin{tabular}{lc}
\hline Age category & Cattle herd composition $(\%, n=1003)$ \\
\hline Work oxen & 27.9 \\
Cows & 26.9 \\
Heifers & 17.1 \\
Young males & 15.8 \\
Male calves & 6.8 \\
Female calves & 5.5 \\
\hline
\end{tabular}

showed that adult draft cattle were valued at USD 427 (SD 48.9) and young male draft cattle at USD 185 (SD 96.3).

All the questionnaire respondents used draft cattle both for plowing their own farms, and hired them out during the two planting seasons. Secondary uses for draft cattle included other heavy manual labor, such as pulling logs. No farmers used their draft cattle for weeding or seeding. Also, the structured questionnaires revealed that on average draft cattle start work at 2.6 years (SD 0.6) and finish at 11.1 years (SD 2.4), resulting in a working life of 8.5 years. Within this time however, farmers indicated a time investment of an average of 18 months (CI: 12.2-23.7) for training, so according to information obtained from the focus group discussions, optimum efficiency was generally not reached until the animal was 4.1 years of age, which tallies with the information obtained from the questionnaires. Analysis of the data obtained from the structured questionnaires indicated that, working a mean $4.3 \mathrm{~h}$ a day (SD 0.4), it takes a pair of draft cattle 2.2 days (SD 0.7) to plow 1 acre of land, equivalent to a working rate of 0.5 acres per day. The average number of annual work days was 51.6 (SD 6.8), consisting of 16.1 days (SD 2.5) on the farmer's own land, 35.3 days (SD 8.2) hired out on other farms, and 0.2 days (SD 0.4) doing other work. Also, the only group whose animals worked mainly on their own farm (64.1\% of days) were the households with only one ox. All households with one work oxen ultimately hired or borrowed extra ones from other farmers. Data on the number of days worked by draft oxen in each household is summarized in Table 2.

All farmers accompanied their draft cattle when they hired them out. The total annual human labor requirement for plowing using draft cattle was calculated as equivalent to 102.8 days, based on 2 people spending an average of 16.1 days annually plowing their own land, and 35.3 days plowing land belonging to others (Table 2). Cash payments for hiring of draft cattle services occurred in $92 \%$ of cases, with the remaining $8 \%$ receiving in-kind payments such as chicken or maize. Farmers charged a daily average rate of USD 8.6 (SD 4.1) for plowing, and USD 4.3 (SD 6.4) for any other draft work. Using focus group discussions and key informant interviews, a comparison was also done between the use of draft cattle and the two main alternatives to draft; hand held hoes and tractors. It was found that it would take 2 people, plowing 3.4 (CI: 2-4.9) hours a day, 12 (CI: 10-13.9) days to plow 1 acre of land using hand held hoes. This is equivalent to a work output of 0.1 acres per day. Thus, the total annual labor that farmers require to plow their own farm using a hand held hoe was estimated at 172.8 labor days (based on 2 people taking 12 days per acre, 2 planting seasons and an average farm size of 3.6 acres). In comparison, it was 
Table 2 Summary of annual pooled data on days worked by draft oxen per household

\begin{tabular}{llrrrrr}
\hline $\begin{array}{l}\text { Number of work } \\
\text { oxen owned per } \\
\text { household }\end{array}$ & $\begin{array}{l}\text { Number of } \\
\text { households } \\
\text { interviewed }\end{array}$ & $\begin{array}{l}\text { Percentage of } \\
\text { interviewed } \\
\text { households }\end{array}$ & $\begin{array}{l}\text { Average days } \\
\text { worked per } \\
\text { work oxen }\end{array}$ & $\begin{array}{l}\text { Number of days } \\
\text { plowing on own } \\
\text { farm }\end{array}$ & $\begin{array}{l}\text { Number of days hired out } \\
\text { for plowing on other } \\
\text { people's farms }\end{array}$ & $\begin{array}{l}\text { Percentage of } \\
\text { plowing days spent } \\
\text { on own farm }\end{array}$ \\
\hline 1 & 20 & 9.8 & 32.9 & 21.1 & 11.8 & 64.1 \\
2 & 151 & 73.7 & 53.4 & 16.0 & 37.4 & 30.0 \\
3 & 22 & 10.7 & 53.1 & 14.5 & 38.6 & 27.3 \\
4 & 11 & 5.4 & 53.5 & 12.2 & 41.3 & 22.8 \\
$4+$ & 1 & 0.5 & 52.0 & 10.0 & 42.0 & 19.2 \\
Whole sample & 205 & 100.0 & 51.6 & 16.1 & 35.3 & 31.2 \\
\hline
\end{tabular}

revealed that a tractor can plow 5.4 (CI: 3.1-7.8) acres a day. Also, data obtained from focus group discussions showed that the hiring rate for a tractor was USD 36.3 (CI: 26.5-46.8) per acre. Table 3 provides a summary of the work output of draft cattle from the analyzed data obtained from the structured questionnaire. The SD for the means is included in the table. Lastly, Table 4 summarizes all the results attained from the focus group discussions and key informant interviews; showing the values and the CI.

Economic analysis of the questionnaires revealed that the total combined annual income (both cash and in kind) from all households from hiring out draft cattle was USD 60 935. An additional benefit, in the form of an averted cost is the cost of human labor that would be used to plow by hand if a farmer did not own his own draft cattle, valued at USD 19997 across 205 households per year.

One year recall showed 40 adult draft cattle across the 205 households were sold during the past year at a total value of USD 17 101. Four draft cattle were "gifted" to others as loan repayments, at a total value of USD 1710 , whilst two were stolen, worth USD 855. Paradoxically, whilst for the cattle owner thefts clearly represent a loss, from the societal point of view they are an output from

Table 3 Draft cattle work output in Tororo district

\begin{tabular}{lcc}
\hline Output Parameter & Duration & $\begin{array}{l}\text { Standard deviation } \\
\text { (SD) }\end{array}$ \\
\hline Age at which work oxen start work & 2.6 & 0.6 \\
Age at which working life ends & 11.1 & 2.4 \\
Time for a pair of draft cattle to plow & 2.2 & 0.7 \\
one acre of land (days) & & \\
Hours worked per day & 4.3 & 0.4 \\
$\begin{array}{lcc}\text { Days worked plowing own farm per } \\
\text { year }\end{array}$ & 16.1 & 2.5 \\
$\begin{array}{l}\text { Days worked plowing other people's } \\
\text { farm per year }\end{array}$ & 35.3 & 8.2 \\
$\begin{array}{l}\text { Days worked doing other draft work } \\
\text { per year }\end{array}$ & 0.2 & 0.4 \\
\begin{tabular}{l} 
Total days worked per year \\
\hline
\end{tabular} & 51.6 & 6.8 \\
\hline
\end{tabular}

the livestock farm. The total value of draft output and draft cattle offtake was therefore USD 100 598. The total number of draft cattle bought in one year by the 205 households was 30, at a total value of USD 5 561. A further four young animals were received as gifts into the herd, valued at USD 1 710, resulting in a total value of draft cattle into the herd of USD 7 271. At the start of the 12 month period, the total opening draft cattle valuation was USD 174417 and at the end of the year the closing valuation was USD 148 966. Thus, the herd value (closing valuation minus opening valuation) was negative USD -25 421. Sensitivity analysis was done to find out the effect of death on the closing herd value and the change in herd value for a 'without death' scenario was just positive, coming to USD 628.6. It is noteworthy that draft animals at the end of their working life were always sold for money, with no informal transfers out of the herd or home slaughter taking place.

The variable costs consisted first, of the cost of keeping the draft animals (animal health inputs, vector control, feed, ropes, fines for crop damage), second, of occasional costs for replacing sick or absent draft animals and third, of the value of the farmers' labor expended on draft work, either on the household's farm or when accompanying draft animals that were hired out. Trypanosomiasis was

Table 4 Summary of all results obtained from secondary data sources

\begin{tabular}{ll}
\hline Parameter & Value $(95 \%$ Cl) \\
\hline $\begin{array}{l}\text { Price of local labor at peak agricultural } \\
\text { activity (in USD) }\end{array}$ & $1.6(1.2-2.0)$ \\
$\begin{array}{l}\text { Mean rural income per person per month } \\
\text { in Tororo district (in USD) }\end{array}$ & $38.8(30.4-47.3)$ \\
$\begin{array}{l}\text { Period taken by } 2 \text { people to plow } 1 \text { acre } \\
\text { of land (in days) }\end{array}$ & $12(10-13.9)$ \\
$\begin{array}{l}\text { Period worked by } 2 \text { people per day to plow } \\
1 \text { acre of land using hand held hoe (in hours) }\end{array}$ & $3(2-3.9)$ \\
$\begin{array}{l}\text { Duration of time taken to train young male } \\
\text { cattle for work (in months) }\end{array}$ & $18(12.2-23.7)$ \\
$\begin{array}{l}\text { Size of land plowed by a tractor per day (in acres) } \\
\text { Hiring rate of tractor per acre (in USD) }\end{array}$ & $5.4(3.1-7.8)$ \\
\hline
\end{tabular}


perceived to be the most common disease affecting cattle in the district, mentioned by $98.2 \%$ of the farmers. East Coast fever was mentioned by $36.8 \%$ of the respondents. Households indicated an average of 13.6 days (SD 8.1) lost to work per year as a result of diseased cattle, resulting in a total 2788 days of lost work over the 205 households. The total variable cost for all the sampled households was USD 17 522. Given the total livestock output was USD 67 905 and the total variable cost as USD 17 517, then the total gross margin for all the households was USD 50383 as shown in Table 4.

The income (cash and income in kind excluding value of home labor saved) received for hiring draft oxen for plowing per household was USD 297 while that from other components of draft oxen output was USD 34 per household giving a total livestock output per household of USD 331. The average variable costs incurred per household came to USD 86. By subtracting variable costs from livestock output, then average gross margin for each draft cattle enterprise comes to USD 245 per year as shown in Table 5.

The net cash income received per household using draft cattle was also calculated. The total cash received (excluding income in kind and home labor cost averted) for hiring out draft oxen for plowing was USD 278, other draft work USD1 and sale of draft oxen was USD 83 per household totaling USD 362. However, each household used USD 27 to purchase draft oxen and incurred monetary variable costs of USD 36 thus the net cash income per household was USD 299 as shown in Table 7.

A sensitivity analysis on labor cost was done to ascertain its effect on the total and household gross margin. Using $50 \%$ of the labor cost (USD 0.8) on all calculations; the

Table 5 Draft cattle enterprise gross margin calculation for the whole study sample

\begin{tabular}{ll}
\hline Item & Value (USD) \\
\hline $\begin{array}{l}\text { a) Total value of livestock products, animals sold } \\
\text { or transferred out of the herd }\end{array}$ \\
- Annual income from hiring out draft cattle & 60935 \\
- Animals sold & 17101 \\
- Animals given out as loan repayments & 1710 \\
- Value of animals stolen & 855 \\
- Value of human labor saved & 19997 \\
Subtotal (a) & 100598 \\
b) Total value of animals brought in to the herd & 7271 \\
c) Change in herd value during the year & -25421 \\
d) Total livestock output (a-b +c) & 67905 \\
e) Total variable cost & -17522 \\
f) Total gross margin (d-e) & 50383 \\
\hline
\end{tabular}

total gross margin of all households was USD 56917 or USD 278 per household and the contribution of draft power to the total livestock output per household was $75.5 \%$ while using $100 \%$ of the labor cost it was USD 80 575, USD 393 and $53.2 \%$ respectively.

\section{Discussion}

The herd composition revealed that draft cattle represented $43.7 \%$ of the cattle owned by draft cattle keepers and that $49.2 \%$ of cattle kept were male. This contrasts with the composition of herds kept by farmers or pastoralists focusing on milk production and herd growth, where females usually account for over two thirds of the herd, for example $70 \%$ in Maasai herds with $60 \%$ of the herd consisting of cows and weaned heifers [40]. The herd structure found in Tororo corroborates other information from Africa, such as: Zimbabwe where draft cattle represented $40 \%$ of the total cattle herd in communal areas [21], southern Mozambique where $25 \%$ of the herd are work oxen [41] and Serere district (Uganda) where $36 \%$ of the cattle were used for draft [42].

Overall, the benefits of using draft cattle greatly exceeded the cost of keeping them; the total gross margin for each household due to draft cattle enterprises was positive (USD 245), indicating their use was highly profitable. Studies done in Botswana [43], South Africa [44] and northern Ghana [45] also found this to be the case. In Tororo, the study revealed that draft oxen add substantially to farmers' cash income, largely through cash payments received from hiring them out, since the average net cash income from hiring of USD 299 per household, was actually higher than the draft cattle enterprise gross margin of USD 245. This was because the value of negative non-cash items in the gross margin calculation (such as reduced herd value, animals transferred into the herd and variable costs) was greater than that of the positive non-cash items (such as payments in kind for hiring draft oxen, home labor saved and animals transferred out of the herd) as shown in Tables 6 and 7. These values obtained are comparable to those estimated for South Africa [46] where own farm plowing was valued at USD 177, lending animals out for plowing at USD 11 and hiring them out at USD 29 per household.

Table 6 Draft cattle enterprise gross margin calculation per household

\begin{tabular}{ll}
\hline Item description & Value (USD) \\
\hline - Income from draft oxen power (including the & 297 \\
value of home labor saved) & \\
- Other components of draft oxen output & 34 \\
Total livestock output & 331 \\
- Variable costs & 86 \\
Total gross margin from using draft oxen & 245
\end{tabular}


Table 7 Draft cattle enterprise net cash income calculation per household

\begin{tabular}{ll}
\hline Item description & Value (USD) \\
\hline $\begin{array}{l}\text { - Cash received from hiring out draft cattle for } \\
\text { plowing and other draft work }\end{array}$ & 279 \\
- Cash received from sale of draft oxen & 83 \\
Subtotal & 362 \\
- Draft oxen bought & 27 \\
- Variable costs & 36 \\
Subtotal & 63 \\
Net cash received per household & 299 \\
\hline
\end{tabular}

The average annual cash earned per adult in the study area is estimated at USD 465 [47]. Considering the average number of adults per household in the study was 2.6, the average annual monetary receipts per household would be USD 1 209. The monetary receipts from using draft oxen came to USD 299 per draft-animal keeping household (Table 7), equivalent to $24.7 \%$ of this figure.

Given income (both cash and in kind) received from the use of draft cattle for each household was USD 297 and from other components of output was USD 34, then the income from hiring out draft power represented $89.7 \%$ of the total livestock output per household. Therefore the main benefit of using draft oxen in Tororo district was income generated from draft power. It should be noted that farmers owning 2 or more draft cattle contributed most of the pooled income gained from draft cattle hire as they compose $88.2 \%$ of draft cattle keepers in Tororo district.

A person with no draft cattle has three alternatives; a) to hire in draft oxen from another farmer, b) use manual labor (a hand held hoe) or c) use a tractor. To hire a pair of oxen costs a non-draft keeper USD 19 per acre. Hiring two manual laborers would cost USD 14 per acre and hiring a tractor would cost USD 36 per acre. Use of draft cattle for plowing is therefore less costly than tractors, but more costly than use of a hand held hoe, however, manual labor has the lowest daily work output, thus being a more expensive option in the long term. More importantly, in rural areas such as Tororo district, the majority of farmers rely on rain-fed agriculture, thus timely preparation of land for crop planting is critical to ensure a high crop yield. Lack of animal traction can therefore lead to planting delays or even to land being left fallow; as demonstrated by studies in Zimbabwe that estimated planting delays could lead to yield losses of 1-3\% per day [48]. Draft cattle use also offsets the drudgery associated with plowing with human power using a hand held hoe. Thus, ownership of draft cattle meant that the total labor requirement for their own farm was only 32.2 days per household, compared to the 172.8 labor days that would have been required if they used manual labor, freeing up substantial time for farmers to do other work. The results from the current study therefore demonstrate animal traction to be an efficient means of land preparation, contributing to improved food security by reducing the likelihood of crop failure.

The $3.4 \%$ annual mortality rate of draft cattle was perceived by farmers to be almost entirely due to disease, resulting in a reduced herd value that ultimately affected the gross margin. Work days lost due to draft cattle illness was calculated at 13.6 days per year per household, which when added to the current number of days worked per year (51.6) equates to a potential of 65.2 days per year that could be worked if cattle did not become sick. Therefore across 205 households, the total lost income as a result of livestock disease was USD 23 898, equivalent to a decrease of $32.2 \%$ of the potential total gross margin from use of draft oxen per household. The reduced work capacity as a result of livestock disease in this study was $20.9 \%$, in addition to the aforementioned loss of household income, this severely impacts the wider community through lack of available animals for plowing other people's farms, extra human effort required to hand plow, and potentially reduced crop yields as a result of delays in plowing [48] with an ultimate effect on overall food security.

Overall, use of gross margin analysis proved an effective methodology for assessment of the economic contribution of draft animal power at the household level in terms of income generation and labor saving. However, one of the challenges of using gross margin analysis in this way is extrapolating findings to the macro-economic level in order to achieve policy impact. This is particularly important in that, ultimately animal traction is not an end product but an input into crop output, hence not directly reflected in national accounts or most livestock models. Therefore, the authors recommend complementing it with other economic models and accounting frameworks such as Food and Agriculture Organization of the United Nation's (FAO) System of Economic Accounts for Food and Agriculture (SEAFA) [49]. At the micro-economic level there is still farm level research work to be done on quantifying the impact of animal traction on crop yields and on the size of the cropped area per household and hence the overall impact of endemic bovine diseases.

\section{Conclusions}

This research is among the few studies in recent years in Africa, and the first evidence from Uganda, to quantify the socioeconomic impact of using animal traction in a mixed crop-livestock production system in which bovine parasitic diseases are endemic. It indicates animal traction to be a highly profitable enterprise at the household level, not just in terms of its contribution to crop production but also its various roles in livelihoods sustainability such 
as household income generation, cattle sales and social capital. However, endemic production-limiting parasitic diseases such as trypanosomiasis and tick-borne diseases reduce draft oxen work output and household income; increasing farmers' vulnerability to economic and food insecurity. Therefore, the need for appropriate systemic investments in animal health service delivery and the promotion of animal traction as a means of improving rural livelihoods is an important recommendation to come out of this research.

\section{Abbreviations}

Cl: credibility interval (95\%); SD: standard deviation; USD: United States Dollar.

\section{Competing interests}

The authors declare that they have no competing interests.

\section{Authors' contributions}

WO was responsible for conception, design, collection, drafting and analysis of data. DM was involved in design and data collection. EM was involved in design and drafting of the manuscript. SW was involved in revising the intellectual content and gave the final approval of the version to be published. CW was involved in design and coordinating fieldwork. AS was involved in conception, design and revising intellectual content. All authors read and approved the final version of the manuscript.

\section{Acknowledgements}

We would like to thank the farmers in Tororo for providing the data. We also appreciate the assistance provided by the Tororo district Veterinary office staff and enumerators for coordinating the field work and data collection. We thank the University of Edinburgh for providing funds for the field work and preparing the manuscript. WO would like to acknowledge the Commonwealth Scholarship Commission who funded his studies on the International Animal Health programme. The questionnaire was adapted by the authors from questionnaires developed under two projects: ICONZ (Integrated Control of Neglected Zoonoses, which was funded under the European Union's Seventh Framework Program [FP7/2007-2013] under grant agreement $n^{\circ}$ 221948) and DFID-RIU (Department for International Development - Research into Use). We are grateful to John Morton and Catherine Butcher whose contributions to the DFID-RIU questionnaires used in Uganda underpinned some of the questions used.

\section{Author details}

${ }^{1}$ Division of Infection and Pathway Medicine, School of Biomedical Sciences, College of Medicine and Veterinary Medicine, University of Edinburgh, Edinburgh, United Kingdom. '2Department of Biomolecular and Biolaboratory Sciences, School of Biosecurity, Biotechnical and Laboratory Sciences, College of Veterinary Medicine Animal Resources and Biosecurity, Makerere University, P.O. Box 7062, Kampala, Uganda. ${ }^{3}$ Avia-GIS, Risschotlei 33, B-2980 Zoersel, Belgium.

Received: 17 November 2014 Accepted: 1 November 2015 Published online: 05 November 2015

\section{References}

1. Jolly CM, Gadbois M. The effect of animal traction on labour productivity and food self sufficiency: the case of Mali. Agr Syst. 1996;51(4):453-67.

2. Teweldmehidin MY, Conroy AB. The economic importance of draught oxen on small farms in Namibia's Eastern Caprivi Region. Afri J Agric Res. 2010;5(9):928-34.

3. Jaeger W, Matlon P. Utilization, profitability and adoption of animal draft power in West Africa. Am J Agri Econ. 1990;72:35-48.

4. Pingali $P$, Bigot $Y$, Binswanger $H$. The driving force of intensification. In: Agricultural mechanization and the evolution of farming systems in Sub-Saharan Africa. Baltimore and London: The Johns Hopkins University Press; 1987. p. 43-55.
5. Adenisa AA. Oxen cultivation in semi-arid West Africa: profitability analysis in Mali. Agr Syst. 1992;38(2):131-47.

6. Randela R. An economic assessment of the value of cattle to the rural communities in the former Venda region. Dev South Afr. 2003;20(1):89-103.

7. Guthiga PM, Karugia JT, Nyikal RA. Does use of animal power increase economic efficiency of smallholder farms in Kenya? Renew Agr Food Syst. 2007;22(4):290-6.

8. Swallow BM. Impacts of Trypanosomiasis on African Agriculture. Programme Against African Trypanosomosis (PAAT) Technical and Scientific Series 2. Rome: Food and Agriculture Organization of the United Nations (FAO); 1999. http://www.fao.org/ag/againfo/programmes/en/paat/documents/ papers/Paper_1999.pdf Accessed 25 May 2012.

9. Okello A. Opportunities for NGOs involved with the draught sector to contribute to national livestock policy frameworks in developing countries. In: Rogers $P$, editor. Proceedings of the 6 th International colloquium on working equids. 2010. p. 80-2.

10. Shaw A, Hendrickx G, Gilbert M, Mattioli R, Codjia V, Dao B, et al. Mapping the benefits: a new decision tool for tsetse and trypanosomiasis interventions. Research Report, Department for International Development, Animal Health Programme, Centre for Tropical Veterinary Medicine, University of Edinburgh and PAAT. Rome: FAO; 2006. http://www.fao.org/ ag/againfo/programmes/en/paat/documents/papers/Paper_2006.pdf. Accessed April 182012.

11. Shaw A, Cecchi G, Wint W, Mattioli R, Robinson T. Mapping the benefits to livestock keepers from controlling animal trypanosomiasis in eastern Africa. Prev Vet Med. 2014;113(2):197-210.

12. Reardon T, Barrett C, Kelly V, Savadogo K. Policy reforms and sustainable agricultural intensification in Africa. Dev Policy Rev. 1999;17(4):375-95.

13. Powell JM, Pearson RA, Hiernaux PH. Crop-Livestock Interactions in the West African Drylands. Agronom J. 2004;96:469-83.

14. McIntire J, Gryseels G. Crop-Livestock interactions in Sub-Saharan Africa and their implications for farming systems research. Exp Agr. 1987;23(3):235-43.

15. Eisler MC, Magona JW, Jonsson NN, Revie CW. A low cost decision support tool for the diagnosis of endemic bovine infectious diseases in the mixed crop-livestock production system of sub-Saharan Africa. Epidemiol Infect. 2007;135(01):67-75.

16. Perry BD, Randolf TF. Improving the assessment of the economic impact of parasitic diseases and of their control in production animals. Vet Parasitol. 1999;84(3-4):145-68

17. Pingali $P$, Bigot $Y$, Binswanger $H$. Agricultural Mechanization and the Evolution of Farming Systems in Sub-Saharan Africa. Baltimore and London: The Johns Hopkins University Press; 1987. ISBN 0-8018-3502-X.

18. Muhanguzi D, Okello WO, Kabasa JD, Waiswa C, Welburn SC, Shaw APM. Cost analysis of options for management of African animal trypanosomiasis using interventions targeted at cattle in Tororo District; south-eastern Uganda. Parasit Vectors. 2015;8:387.

19. Williams TO. Problems and prospects in the utilization of animal traction in semi-arid West Africa: evidence from Niger. Soil Till Res. 1997;42:295-311.

20. Savadogo K, Reardon T. Pietola K. Adoption of improved land use technologies to increase food security in Burkina Faso: relating animal traction, productivity and non-farm income. Agr Syst. 1998;58(3):441-64.

21. Barrett JC. The economic role of cattle in communal farming systems in Zimbabwe. London, Overseas Development Institute (ODI) Pastoral Development Network Paper 32b. http://www.odi.org.uk/work/projects/ pdn/papers/32b.pdf. Accessed 15 May 2011

22. Rushton J. The economics of animal health and production. Wallingford: CABI; 2009.

23. James $A D$, Carles $A B$. Measuring the productivity of grazing and foraging livestock. Agr Syst. 1996;52(2/3):271-91.

24. Magona JW, Greiner M, Mehiltz D. Impact of tsetse control on the age-specific prevalence of Trypanosomiasis in village cattle in southeast Uganda. Trop Anim Health Pro. 2000;32(2):87-98.

25. Muhanguzi D, Picozzi K, Hattendorf J, Thrusfield M, Welburn SC, Kabasa JD, et al. Prevalence and spatial distribution of Theileria parva in cattle under crop-livestock farming systems in Tororo District, Eastern Uganda. Parasit Vectors. 2014;7:91. doi:10.1186/1756-3305-7-91.

26. Eisler MC, Magona JW, Revie CW. Diagnosis of Cattle Diseases Endemic to Sub-Saharan Africa: Evaluating a Low Cost Decision Support Tool in Use by Veterinary Personnel. PLoS One. 2012;7(7):1-14. doi:10.1371/journal.pone.0040687.

27. Muhanguzi D, Picozzi K, Hattendorf J, Thrusfield M, Kabasa JD, Waiswa C, et al. The burden and spatial distribution of bovine African trypanosomes in 
small holder crop-livestock production systems in Tororo District, SouthEastern Uganda. Parasit Vectors. 2014;7:603. doi:10.1186/s13071-014-0603-6.

28. Picozzi K, Fèvre EM, Odiit M, Carrington M, Eisler MC, Maudlin I, et al. Sleeping sickness in Uganda: a thin line between two fatal diseases. BMJ. 2005;331:1238-42.

29. Zoller T, Fèvre EM, Welburn SC, Odiit M, Coleman PG. Analysis of risk factors for T. Brucei rhodesiense sleeping sickness within villages in south-east Uganda. BMC Infect Dis. 2008:8(88):1-9. doi:10.1186/1471-2334-8-88.

30. Selby R, Bardosh K, Picozzi K, Waiswa C, Welburn SC. Cattle movements and trypanosomes: restocking efforts and the spread of Trypanosoma brucei rhodesiense sleeping sickness in post-conflict Uganda. Parasit Vectors. 2013;6(1):281. doi:10.1186/1756-3305-6-281.

31. Bardosh K, Waiswa C, Welburn SC. Conflict of interest: use of pyrethroids and amidines against tsetse and ticks in zoonotic sleeping sickness endemic areas of Uganda. Parasit Vectors. 2013;6:204. doi:10.1186/1756-3305-6-204.

32. Thrusfield M. Veterinary epidemiology. 3rd ed. Oxford: Blackwell Science Ltd; 2005.

33. University of Columbia, Los Angeles: CSurvey version 2.0. 2008.

34. Web center for Social Methods Research. Cornell Office for Research on Evaluation. http://www.socialresearchmethods.net/. Accessed 11 May 2012.

35. Taylor HM, Karlin S. Introduction to stochastic modeling. Revth ed. Oxford: Academic press Ltd; 1994.

36. Ramberg JS, Tadikimalla PR, Dudewicz EJ, Mykytka EF. A probability distribution and its uses in fitting data. Technometrics. 1979;21:201-14.

37. Oanda: Historical exchange rates. http://www.oanda.com/currency/ historical-rates/. Accessed 11 May 2012.

38. Perkins J, Sabrani M. Economic evaluation of draught animals. In: Teleni E, Campbell RSF, Hoffmann D, editors. Draught animals system and management: an Indonesian study. Canberra: Australian Centre for International Agricultural Research (ACIAR) Monograph series; 1993. p. 77-120.

39. R Development Core Team. R: A language and environment for statistical computing. Vienna: R Foundation for Statistical computing; 2007.

40. Roderick S, Stevenson P, Ndungu J. The production parameters influencing the composition and structure of pastoral cattle herds in a semi-arid area of Kenya. Animal Sci. 1998;66:585-94.

41. Rocha A, Starkey P, Dionisio AC. Cattle production and utilisation in smallholder farming systems in Southern Mozambique. Agr Syst. 1991;37(1):55-75.

42. Ocaido M, Otim CP, Okuna NM, Erume J, Ssekitto C, Wafula RZO, et al: Socio-economic and livestock disease survey of agro-pastoral communities in Serere county, Soroti district, Uganda. Livest Res Rural Dev 2005, 17(8);Article \#93 http://www.lrrd.org//rrd17/8/ocai17093.htm.

43. Panin A. Empirical evidence of Mechanization Effects on smällholder crop production systems in Botswana. Agr Syst. 1995;47:199-210.

44. Simalenga TE, Belete A, Mseleni NA, Jongisa LL. Assessing the profitability of using animal traction under smallholder farming conditions. S Afri Jnl Agric Ext. 2000;29:1-9.

45. Panin A. Profitability assessment of animal traction investment: the case of Northern Ghana. Agr Syst. 1989;30(2):173-86.

46. Dovie DBK, Shackleton CM, Witkowski ETF. Valuation of communal area livestock benefits, rural livelihoods and related policy issues. Land Use Policy. 2006;23(3):260-71.

47. Uganda Bureau of Statistics (UBOS). Employment and Earning Survey Report 2008/2009. http://www.ubos.org/unda/index.php/catalog/3. Accessed 13 July, 2012.

48. Shumba E. Reduced tillage in the communal areas. Zimbabwe J Agr Res. 1984:81(6):235-9.

49. Food and Agriculture Organization of the United Nations. A System of Economic Accounts for Food and Agriculture. Rome, FAO, 1993. http:// www.fao.org/docrep/w0010e/w0010e00.htm. Accessed 13 July 2012.

\section{Submit your next manuscript to BioMed Central and take full advantage of:}

- Convenient online submission

- Thorough peer review

- No space constraints or color figure charges

- Immediate publication on acceptance

- Inclusion in PubMed, CAS, Scopus and Google Scholar

- Research which is freely available for redistribution

Submit your manuscript at www.biomedcentral.com/submit 